\title{
Local Community Participation in the Conservation of the Naga Fireball Festival
}

\author{
Thirachaya Maneenetr \\ Director of Center for Asia-Pacific Tourism Research \\ Faculty of Management Science, Khon Kaen University \\ Email: thirachaya@kku.ac.th
}

Thanh Ha Tran

Master Degree of Tourism Management, Faculty of Management Science, Khon Kaen University Email: cholly.pen@gmail.com

\section{Doi:10.5901/mjss.2014.v5n23p372}

\section{Abstract}

\begin{abstract}
This study aims to investigate problems with local community participation in the Naga Fireball Festival in Phon Phisai District, Nong Khai province, and guidelines to promote local community participation in the conservation of the Naga Fireball Festival in Phon Phisai District. A mix method was applied. The results showed that overall, local community participation in the Naga Fireball Festival was at the high level (mean $=3.57$, S.D. $=0.15$ ). Guidelines to promote local community participation in the conservation of the Naga Fireball Festival in Phon Phisai District, Nong Khai province were proposed which included: 1) designing an official website to promote the Naga Fireball Festival, 2) establishing a learning center about the Naga in Phon Phisai District, 3) promoting homestay for a firsthand experience along the Mekong River, 4) expanding the role of young people in the community in festival planning, and 5) providing tourists' activities based on the Legend of Naga.
\end{abstract}

Keywords: Local community participation, cultural tourism, festival, Naga Fireball Festival

\section{Introduction}

Festivals are a type of cultural event and are travel attractions with unique features (Chang, 2006). Festivals provide the opportunity for visitors to participate in a collective experience that is distinct from everyday life (Getz \& Frisby, 1988) and help to enhance or preserve local culture and history (Xie, 2004). Therefore, festivals and special events have grown rapidly in number throughout the world during the past decade.

As a cultural destination in the northeast of Thailand, Phon Phisai District of Nong Khai province is prominent for the Naga Fireball Festival at the end of the Buddhist Lent (at the beginning of October) which is based on the beliefs of local residents in the Serpent - Naga. Cohen (2007) states that along the Mekong River, there are fireballs allegedly shot, which are believed to be made by the Naga, to pay homage to the Lord Buddha and which also recently became the focus of a major festival that attracts many (mainly domestic) tourists pilgrims. Nowadays, the Naga Fireball Festival plays an important role in the cultural tourism in Phon Phisai district, in particular, and Nong Khai province, in general. This festival has positive impacts on both cultural and economic dimensions. As Gursoy et al. (2004) states festivals play a significant role in communities' lives because they provide important activities and spending outlets for locals and visitors, and enhance the local communities' image. Furthermore, local festivals are increasingly being used as instruments for promoting tourism and boosting the regional economy (Felsenstein \& Fleischer, 2003).

Local festivals have become a part of tourism. Thus, tourism planners are being asked to seek greater community participation in tourism planning. There are two reasons for this. First, the impacts of tourism are felt most keenly at the local destination area and, second, community residents are being recognized as an essential ingredient in the 'hospitality atmosphere' of a destination (Simmons, 1994). Apart from that, local festivals have been frequently based on the local culture and local wisdom. Thus, the role of the local community should be considered during the planning process because their involvement in tourism development can as well be beneficial to tourism development because they can create an effective environmental stewardship that builds on indigenous, local and scientific knowledge, economic development, social empowerment, the protection of cultural heritage and the creation of interpretive and nature-based experiences for tourist learning and cross-cultural appreciation (Jamal \& Stronza, 2009).

Therefore, in this study, the researchers focused on the problems regarding the local communitys' participation in 
the Naga Fireball Festival in Phon Phisai District, Nong Khai province. Concerning this, two questions were raised 1) What problems are there regarding the local communitys' participation in the Naga Fireball Festival in Phon Phisai District, Nong Khai province?, and What guidelines should there be to promote local community participation in the conservation of the Naga Fireball Festival in Phon Phisai District, Nong Khai province?

\section{Literature Review}

\subsection{Festivals and cultural tourism}

Cultural tourism is one of the fastest growing sectors in the global tourism industry and this growth is predicted to accelerate as increasing numbers of tourists visit various cultural attractions in different parts of the world (Akama \& Kieti, 2006). Culture and creative industries are increasingly being used to promote destinations and enhance their competitiveness and attractiveness. Many locations are now actively developing their tangible and intangible cultural assets as a means of developing comparative advantages in an increasingly competitive tourism marketplace, and to create local distinctiveness in the face of globalization (OECD, 2009).

Cultural tourism takes several forms. With the exception of pilgrimages, its main manifestations are either heritage related trips or travel connected with present-day artistic creation. As a form of cultural tourism, festivals have been generating a significant amount of arts travel (Koutoulas, 2004). Lyck et al. (2012) state that an organized set of special events on a specific cultural man-made theme taking place on a specific day or period, normally in a specific place, gathering people in mutual and direct contact to the festival theme. Festivals have frequently been as cultural events which provide interesting activities and spending venues for both local people and tourists (Formica \& Uysal, 1998). Festivals are occasions to interpret various symbolic elements of the social existence of a group or community, with the effect of re-creating social relations and the symbolic foundations underpinning everyday life (Turner, 1982). Nowadays, local festivals are increasingly being used as instruments for promoting tourism and boosting the regional economy (Felsenstein \& Fleischer, 2003). Successful festivals can help recreate the image of a place (Kotler et al., 1993) and help to extend the tourism season of the local calendar (Getz 1997).

\subsection{Background of the Naga fireball festival in Nong Khai province}

The Naga Fireball Festival is based on the supernatural phenomenon in the Mekong River during the end of the Buddhist Lent (at the beginning of October). Local residents along the Mekong River strongly believe that Naga are the Serpents of this river which have the power to protect local residents and bring them a peaceful life. From the Buddhist viewpoint, it is believed that the Naga protect meditators and dispense wisdom. They help to bring rain, personal protection and to grant fertility and wealth (Wood, 2007). At the end of the Buddhist Lent, there are fireballs allegedly shot from the Mekong River, which are believed to be made by the Naga, to pay homage to the Lord Buddha and which also recently became the focus of a major festival that attracts many (mainly domestic) tourist pilgrims (Cohen, 2007).

During the Naga Fireball Festival, many activities take place such as tourism light and sound performances to remind people of the Legend of the Naga. There are also floating decorated boats with splendid lanterns along the Mekong River to pay respect to the Naga. Because the festival is organized at the end of Buddhist lent, making merit and practicing mediation in the temple are usual activities for local Buddhist as well.

Festivals are opportunities for leisure, social, or cultural experiences outside the normal range of choices or beyond everyday experiences (Getz, 1997) and they create memories and stories, highlight mundane everyday experiences, elevate people's spirits, and celebrate human existence (Pan \& Huan, 2013). Therefore, in terms of Nong Khai province, the legend of the Naga and the Naga Fireball Festival play a crucial part in the culture of local living. It is not only a tourist product to attract international tourists, but also reflects the local wisdom and authenticity of the region along the Mekong River.

\subsection{Local community participation}

Murphy (1985) emphasized the importance of local involvement in tourism development. He indicated that the success of tourism relies on the goodwill and cooperation of local people because they are part of the tourism product.

It is generally understood that tourism development affects local communities in terms of economics. While at some destinations locals might be completely dependent on the tourism industry for their income, in other places it might provide a nice way to gain some extra earning besides regular income (Breugel, 2013). For social impact, tourism is one 
of the best placed potential sources of employment opportunities for local communities (Li, 2005). On cultural impact, tourism usually brings new experiences in the encounters between hosts and tourists which have the potential to achieve greater international understanding and harmony (Telfer \& Sharpley, 2008). Apart from positive impacts, the tourism industry brings negative impacts to local communities as well, especially the cultural dimension. The tourism industry is a contributor to globalization which creates all kinds of opportunities for local communities as well as the potential loss of cultural traits (Michael, 2009). Therefore, tourism academicians seems to have achieved an agreement on the view that residents' more active involvements in the tourism development process will be conducive to a more sustainable tourism development in the local community (Briedenhann \& Wickens, 2004).

Community participation in tourism can be examined from at least two perspectives: in the decision-making process and tourism benefits sharing (McIntosh \& Goeldner, 1986). Community participation of the host community in decision making is made specifically to meet basic needs of host communities so as to avoid potential socio-political risks for tourists and tourism development (Tosun, 2006). It is also a crucial determinant to ensure that the benefits local communities get from tourism are guaranteed and their lifestyles and values are respected (Michael, 2009).

\subsection{Tourism destination}

Destination is place where tourists spend their travel and their leisure which include tourism products such as support services and attractions and other tourist resources, basic elements which attract tourists and satisfy their demand on arrival. There are attractions, public and private amenities, accessibility, human resources, image and character and price (World Tourism Organization: UNWTO, 2007). Charlotte \& Ritchie (1991) state that destination is a comprise of attributes to attract tourists such as attractions, activities, local infrastructure, transportation, historic sites, accommodations, exhibits, festivals, facilities, information and tours, personal safety, accessibility, different customs or culture, different cuisine, atmosphere, and opportunity to increase knowledge. This is consistent with what Buhalis (2000) states, that a destination can be regarded as a combination of all products, services and ultimately experiences provided locally. He suggests a core of the following components, which can be defined as the six, including attractions, accessibility, amenities, available packages, activities and ancillary services.

Regarding local community participation in tourism management, local attitudes directly affect the current and future tourism development. Community positive attitudes will encourage tourists' satisfaction levels and contributes to the word-of-mouth promotion among them (Hanafiah et al., 2013). Moreover, Tasci \& Gartner (2007) also suggest that forms of information play a role in determining destination image to communicate destination information to a wider range of tourists. Therefore, advertising activities seem to be a useful mechanic to inform, pursue and remind tourism products of the destination (Morrison, 2013).

Each destination has characteristics and specifics which can be identified by their image. It is necessary to determine and evaluate the core of the destination to incorporate tourism management appropriately.

\section{Research Objectives}

For this research, the following issues of study were specified:

- To study local community participation in the Naga Fireball Festival in Phon Phisai district, Nong Khai province.

- To study guidelines to promote local community participation in the conservation of the Naga Fireball Festival in Phon Phisai District, Nong Khai province.

\section{Research Methodology}

To ensure the study was objective, the researchers employed a mixed method approach as shown below:

\subsection{Population and sample}

The participants in this study were as follows:

- Local community in Phon Phisai district, Nong Khai province. Using Yamane's formula (1973) and 95\% confidence levels, the researchers calculated the sampling size as 400 .

- Eight experts related to cultural tourism and the Naga Fireball Festival in Nong Khai province who included academics, tourism entrepreneurs, representatives of involved public organizations and local philosophers. 


\subsection{Study design}

Research data was conducted from September to November 2013 which is described below:

For quantitative data, questionnaires were created which consisted of two parts 1) demographic information of the local community and 2) local community participation in the Naga Fireball Festival which was divided into the following seven aspects: attitudes, attractions, accessibility, accommodations, activities, amenities and advertising. The questionnaire used a Likert scale with five options: strongly agree, agree, not sure, disagree and strongly disagree. The researchers interpreted the completed questionnaires by dividing the question scale into a 5 point scale, as shown in table 1:

Table 1. Significance of points

\begin{tabular}{|c|c|}
\hline Average Scores & Level of Significance \\
\hline $1.00-1.80$ & Lowest \\
\hline $1.81-2.60$ & Low \\
\hline $2.61-3.41$ & Moderate \\
\hline $3.42-4.20$ & High \\
\hline $4.21-5.00$ & Highest \\
\hline
\end{tabular}

In terms of statistical analysis of the data, mean, standard deviation and Chi square tests were used.

For qualitative data, a focus group discussion was organized. Eight experts who included academics, tourism entrepreneurs, representatives of involved public organizations and local philosophers discussed appropriate ways to promote local community participation in conservation of the Naga Fireball Festival. Data analysis was performed using descriptive analysis.

\section{Research Area}

Nong Khai province is located in the northeast of Thailand. It is a Thai - Lao border province which is 514 kilometers away from BangKok. Nong Khai province has 3,026.5 square kilometers which includes six districts. In this study, the researchers focused on Phon Phisai, a district in Nong Khai province. This district is popular with tourists because of the Naga fireball phenomenon. In Phon Phisai district, more and more domestic and international tourists arrive yearly to enjoy the Naga fireball phenomenon along the Mekong River and attend activities during the Naga Fireball Festival.

Figure 1. Research area

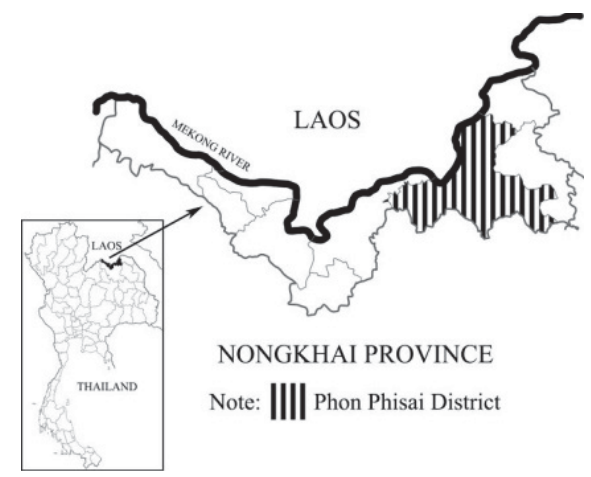

\section{Research Results}

6.1 Local community participation at the Naga fireball festival in Phon Phisai Distrist, Nong Khai province. 
Table 2. Local community participation at the Naga Fireball Festival in Phon Phisai District, Nong Khai province.

\begin{tabular}{|c|c|c|c|}
\hline Items & $\bar{x}$ & S.D. & Interpretation \\
\hline \multicolumn{4}{|l|}{ Attitudes } \\
\hline Community supports tourists' activities dealing with the Naga Fireball Festival & 3.67 & 0.82 & High \\
\hline Community shares opinions in planning the Naga Fireball Festival & 2.77 & 0.71 & Moderate \\
\hline Community has applied local wisdom in management of the Naga Fireball Festival & 3.36 & 0.75 & Moderate \\
\hline \multicolumn{4}{|l|}{ Attractions } \\
\hline Community maintains clean and fresh landscape & 4.11 & 0.70 & High \\
\hline Community carries on local history and legend of the Naga & 3.71 & 0.82 & High \\
\hline Organizing of light and sound presentations about the Legend of the Naga & 2.63 & 0.70 & Moderate \\
\hline Floating decorated boats with colorful lanterns to pay respect to the Naga & 3.07 & 0.82 & Moderate \\
\hline Making merit on the final day of the Lenten Season & 4.28 & 0.68 & High \\
\hline \multicolumn{4}{|l|}{ Accessibility } \\
\hline Maps and directions to the community & 3.38 & 0.91 & Moderate \\
\hline Community improves road conditions & 3.10 & 0.89 & Moderate \\
\hline Clearly labeled signposts in the community & 3.20 & 0.97 & Moderate \\
\hline Community focuses on safety and security of tourists & 4.47 & 0.50 & High \\
\hline \multicolumn{4}{|l|}{ Accommodations } \\
\hline Accommodation management to facilitates tourists & 4.17 & 0.75 & High \\
\hline Creating accommodation themes to interpret lifestyles along the Mekong River & 4.16 & 0.75 & High \\
\hline Arranging clean local lodging & 4.23 & 0.64 & High \\
\hline Facilitates of accommodations & 3.37 & 0.97 & Moderate \\
\hline \multicolumn{4}{|l|}{ Activities } \\
\hline Tourists' activities based on legend of the Naga & 3.11 & 0.85 & Moderate \\
\hline $\begin{array}{l}\text { Enhancing awareness of lifestyle and culture along the Mekong River from the Naga Fireball } \\
\text { Festival }\end{array}$ & 4.08 & 0.84 & High \\
\hline Supporting connections between local community and tourists & 4.35 & 0.67 & High \\
\hline Local guides from community & 3.01 & 0.81 & Moderate \\
\hline \multicolumn{4}{|l|}{ Amenities } \\
\hline Community improves infrastructure for tourists (electricity/ water supply) & 3.16 & 0.71 & Moderate \\
\hline Public transportation available to support festival activities & 3.76 & 0.75 & High \\
\hline Local dishes to serve tourists & 4.56 & 0.49 & Highest \\
\hline \multicolumn{4}{|l|}{ Advertising } \\
\hline Readiness of information sources about the Naga Fireball Festival & 2.99 & 0.69 & Moderate \\
\hline Up-to-date tourist information about the Naga Fireball Festival & 2.84 & 0.77 & Moderate \\
\hline Reliable sources of information about the Naga Fireball Festival & 3.86 & 0.72 & High \\
\hline Total & 3.57 & 0.15 & High \\
\hline
\end{tabular}

Table 2 shows this study's results regarding local community participation in the Naga Fireball Festival, each aspect of these findings is interpreted below:

For attitudes, Community supports tourists' activities dealing with the Naga Fireball Festival was at the high level (mean $=3.67$, S.D. $=0.82$ ). Community shares opinions in planning the Naga Fireball Festival was at the moderate level (mean $=2.77$, S.D. $=0.71$ ). Community has applied local wisdom in management of the Naga Fireball Festival was at the moderate level (mean $=3.36$, S.D. $=0.75)$.

In terms of attractions, Community maintains clean and fresh landscape was at the high level (mean $=4.11$, S.D. $=$ 0.70). Community carries on local history and legend of the Naga was at the high level (mean $=3.71$, S.D. $=0.82$ ). Making merit on the final day of the Lenten Season was at the high level (mean $=4.28$, S.D. $=0.68$ ). Organizing of light and sound presentations about the Legend of the Naga was at the moderate level (mean $=2.63$, S.D. $=0.70)$. Floating decorated boats with colorful lanterns to pay respect to the Naga was at the moderate level (mean = 3.07, S.D. $=0.82$ ).

On accessibility, Community focuses on safety and security of tourists was at the high level (mean $=4.47$, S.D. $=$ 0.50). Maps and directions to the community was at the moderate level (mean $=3.38$, S.D. $=0.91$ ). Community improves road conditions was at the moderate level (mean $=3.10$, S.D. $=0.89$ ). Clearly labeled signposts in the community was at the moderate level $($ mean $=3.20$, S.D. $=0.97$ ).

For accommodations, Accommodation management to facilitates tourists was at the high level (mean $=4.17$, S.D. $=0.75$ ). Creating accommodation themes to interpret lifestyles along the Mekong River was at the high level (mean = 
4.16, S.D. $=0.75)$. Arranging clean local lodging was at the high level $($ mean $=4.23$, S.D. $=0.64)$. Facilitates of accommodations was at the moderate level (mean $=3.37$, S.D. $=0.97$ ).

On activities, Enhancing awareness of lifestyles and culture along the Mekong River from the Naga Fireball Festival was at the high level (mean $=4.08$, S.D. $=0.84$ ). Supporting connections between local community and tourists was at the high level (mean $=4.35$, S.D. $=0.67$ ). Tourists' activities based on the legend of the Naga was at the moderate level $($ mean $=3.11$, S.D. $=0.85)$. Local guides from community was at the moderate level (mean = 3.01, S.D. $=0.81$ ).

For amenities, Local dishes to serve tourists was at the highest level (mean $=4.56$, S.D. $=0.49$ ). Public transportation available to support festival activities was at the high level (mean $=3.76$, S.D. $=0.75$ ). Community improves infrastructure for tourists (electricity/ water supply) was at the moderate level (mean $=3.16$, S.D. $=0.71$ ).

In terms of advertising, Reliable sources of information about the Naga Fireball Festival was at the high level (mean $=3.86$, S.D. $=0.72$ ). Readiness of information sources about the Naga Fireball Festival was at the moderate level (mean $=2.99$, S.D. $=0.69)$. Up-to-date tourist information about the Naga Fireball Festival was at the moderate level $($ mean $=2.86$, S.D. $=0.77)$.

Overall, local community participation in the Naga Fireball Festival was at the high level with each aspect from the highest level to the lowest level shown in table 3.

Table 3. Summary of local community participation in seven aspects of the Naga Fireball Festival

\begin{tabular}{|c|c|c|c|}
\hline Items & $\bar{x}$ & S.D. & Interpretation \\
\hline Attractions & 3.56 & 0.34 & high \\
\hline Accessibility & 3.54 & 0.42 & high \\
\hline Accommodations & 3.98 & 0.40 & high \\
\hline Activities & 3.62 & 0.37 & high \\
\hline Amenities & 3.82 & 0.38 & moderate \\
\hline Attitudes & 3.27 & 0.43 & moderate \\
\hline Advertising & 3.57 & 0.15 & high \\
\hline Total & 3.57 & $\mathbf{0 . 1 5}$ & \\
\hline
\end{tabular}

Table 2 shows that local community participation in the Naga Fireball Festival in terms of attractions (mean $=3.56$, S.D. $=$ 0.34 ), accessibility (mean $=3.54$, S.D. $=0.42$ ), accommodations (mean $=3.98, S . D .=0.40$ ), activities (mean $=3.62$, S.D. $=0.37$ ), and amenities (mean $=3.82$, S.D. $=0.38$ ) were all at the high level while attitudes (mean $=3.27$, S.D. $=0.43$ ) and advertising (mean $=3.57$, S.D. $=0.15$ ) were at the moderate level.

\subsection{Guidelines to promote the local community in the conservation of the Naga fireball festival in Phon Phisai district, Nong Khai province}

A focus group discussion was organized. Eight experts who included academics, tourism entrepreneurs, representatives of involved public organizations and local philosophers discussed the background of the Naga Fireball Festival and the results of local community participation in the Naga Fireball Festival. Guidelines to promote local community participation in the conservation of the Naga Fireball Festival in Phon Phisai District, Nong Khai province were proposed as shown below:

\subsubsection{Designing an official website to promote the Naga Fireball Festival}

Nong Khai province is known as the city of the serpent - Naga and Phon Phisai district seem to be the original destination of the Naga fireballs. Thus, it is important to consider reliable and credible sources of cultural tourism information about the Naga Fireball Festival in Phon Phisai District. Moreover, establishing various types of information sources and accessibility of that information can better identify the destination's image. Therefore, the local government office in Phon Phisai district should design an official website about the Naga Fireball Festival. This website should include background on the Legend of the Naga and the beliefs about the Naga of local residents along the Mekong River which can be confirmed by local philosophers. Besides this, there should be more foreign languages and more ways to find out tourism information. This is the reason the website should be written in Thai and English. 


\subsubsection{Establish a learning center about the Naga in Phon Phisai District}

The Naga Fireball Festival is based on the strong beliefs of the local community. In this respect, the local community should establish a learning center about the Naga. This learning center should have exhibitions about the legend of the Naga, collections of writings about local beliefs on the Naga and local rituals to pay respect to the Naga. It would mainly be administrated and planned by committees from the local community to ensure truthful and authentic information. Moreover, the local government and involved private and public organizations should provide a budget for its establishment and for public relation activities for the Naga learning center in Phon Phisai District.

\subsection{Promoting homestay for a firsthand experience along the Mekong river}

The legend of the Naga and the belief in the Naga fireballs is related to the Mekong River and local life along the Mekong River bank. That is why a Homestay program should be supported and promoted in the local communities in Phon Phisai District. The Mekong River Homestay would provide a firsthand experience to tourists about the way of life in Phon Phisai District, in particular, and along this river in general. Local communities can communicate their way of life by fishing and boating along the Mekong River, making food from local ingredients and through rituals that pay homage to the goddess of the Mekong River and the Naga Serpents. Tourists are welcome to be a part of these activities as well. Therefore, the local community and tourists have a chance to connect with each other and enhance their attitudes about each different culture. In this way, local communities can remain the core of the Naga Fireball Festival. Additionally, extra income from Homestay would also increase the quality of life for the local communities.

\subsection{Expanding the role of young people in the community in festival planning}

Young people in the community play an important role to in conserving and taking care of the core elements of the Naga Fireball Festival. During the Naga fireball festival, young people in the community can be local guides or staff to serve tourists. As a part of Phon Phisai District, they understand the behavior and discipline needed when attending the Naga Fireball Festival which should be displayed by tourists. Participating in festival planning creates jobs and income in the community and establishes a bond between the younger generation and their homeland.

\subsection{Tourist activities based on the legend of the Naga}

Frequently, tourists attend to see the fireballs shot naturally in the Mekong River and enjoy sightseeing and performances. But, the Naga Fireball Festival is based on local culture. Thus, the local communities should have the main role in planning tourists' activities to retain the authentic and the core elements of the festival and the Legend of the Naga. Traditional activities at the end of Buddhist Lent which are organized and taken care of by local communities from generation to generation should be considered and promoted. There are rituals to pay homage to the Naga, making merit and meditation practice in local temples. It is so crucial to interpret the core elements of Naga Fireball Festival to tourists and enhance their awareness on the local communities along the Mekong River.

\section{Conclution}

In this study, the researchers investigated local community participation in the Naga Fireball Festival in Phon Phisai District, Nong Khai province, and guidelines to promote local community participation in the conservation of the Naga Fireball Festival in Phon Phisai District, Nong Khai province. A Mix method was applied to collect and analyze data. The results showed that, overall, local community participation in the Naga Fireball Festival was at the high level. This includes local community participation in terms of attractions (mean $=3.56$, S.D. $=0.34$ ), accessibility (mean $=3.54$, S.D. $=0.42$ ), accommodations (mean $=3.98$, S.D. $=0.40$ ), activities (mean $=3.62$, S.D. $=0.37$ ), and amenities (mean $=3.82$, S.D. $=0.38)$ which were all at the high level while attitudes (mean $=3.27$, S.D. $=0.43)$ and advertising (mean $=3.57$, S.D. $=0.15$ ) were at the moderate level.

A focus group discussion was held which proposed guidelines to promote local community participation in the conservation of the Naga Fireball Festival in Phon Phisai District, Nong Khai province which were 1) designing an official website to promote the Naga Fireball Festival, 2) establishing a learning center about the Naga in Phon Phisai District, 3) promoting Homestay for a firsthand experience along the Mekong River, 4) expanding the role of young people in the community in festival planning, and 5) providing tourists' activities based on the Legend of the Naga. 


\section{References}

Akama, J. S. \& Kieti, D. M. (2006). The Role of Local Communities in Tourism Product Rejuvenation and Cultural Tourism Development in Kenya. A Case Study of The Samburu Ethnic Community. African Journal of Business and Economics, 1 (1): 110-121.

Buhalis, D. (2000). Marketing the Competitive destination of the future. Tourism Management, 21, 97-116.

Breugel, L.V. (2013). Community-based tourism: Local participation and perceived impacts. A comparative study between two communities in Thailand. Faculty of Social Sciences. Radboud University Nijmeges. Retrieved from ttp://www.ru.nl/publish/pages/ 657546/thesis_liedewij_van_breugel_scs.pdf.

Briedenhann, J. \& Wickens, E. (2004). Tourism routes as a tool for the economic development of rural areas-vibrant hope or impossible dream? Tourism Management, 25 (1), 71-79.

Chang, J. (2006). Segmenting tourists to aboriginal cultural festivals: An example in the Rukai tribal area, Taiwan. Tourism Management, 27(6), $1224-1234$.

Echtner, C.M. \& Ritchie, J.R.B. (1991). The meaning and measurement of destination image. The Journal of Tourism Studies, 2(2): 1-11

Cohen, E. (2007). The "Postmodernization" of a Mythical Event: Naga Fireballs on the Mekong River. Tourism Culture \& Communication,7(3),169-181.

Felsenstein, D. \& Fleischer, A. (2003). Local festivals and tourism promotion: The role of public assistance and visitor expenditure. Journal of Travel Research, 41 (4), 385-392.

Formica, S. \& Uysal, M. (1998). Market Segmentation of An International Cultural - Historical Event in Italy. Journal of Travel Research, 36(4) $16-24$.

Getz, D. \& Frisby, W. (1988). Evaluating management effectiveness in community-run festivals. Journal of Travel Research, 27 (1), $22-$ 27.

Getz, D. (1997). Festival Management and Event Tourism. Elmsford, NY: Cognizant Communications.

Gursoy, D., Kim, K. \& Uysal, M. (2004). Perceived impacts of festivals and special events by organizers: an extension and validation. Tourism Management 25(2), $171-181$.

Hanafiah, M.H., Jamaluddin, M.R. \& Zulkifly, M,I, (2013). Local Community Attitude and Support towards Tourism Development in Tioman Island, Malaysia. Procedia - Social and Behavioral Sciences, 105 (3), 792 - 800.

Jamal, T. \& Stronza, A. (2009). Collaboration theory and tourism practice in protected areas: Stakeholders, structuring and sustainability. Journal of Sustainable Tourism, 17, 169-189.

Kotler, P., D. H. Haider, \& I. Rein (1993). Marketing Places: Attracting Investment, Industry and Tourism to Cities, States and Nations. New York: Free Press.

Koutoulas, D. (2004). Developing Cultural Tourism through the Athens Festival. UK: The centre of tourism and Cultural Change. Sheffield Hallam University.

Li, W. (2005). Community decision-making: participation in development, Annals of Tourism Research, 33 (1) 132-143.

Lyck. L., Long, P., Grige, A.X. (2012). Tourism, Festivals and Cultural Events in Times of Crisis. Denmark: Copenhagen Business School Publications.

McIntosh, R.W. \& Goeldner, G. R. (1986). Tourism: Principles, practices, philosophies. 5th ed. New York : Wiley.

Michael, M. (2009). Community involvement and participation in tourism development in Tanzania: A Case Study of Local Communities in Barabarani Village, MTO WA MBU, Arusha - Tanzania. Victoria University of Wellington. Retrieved from http://researcharchive.vuw.ac.nz/xmlui/bitstream/handle/10063/968/thesis.pdf?sequence=1.

Morrison, A.M. (2013). Marketing and management tourism destination. London: Routledge.

Murphy, P.E. (1985). Tourism: A Community Approach. London: Routledge.

OECD. (2009). The Impact of Cultural Tourism. Paris: OECD.

Pan, B. \& Huan, T. (2013) "New perspectives on festival and events research", International Journal of Culture, Tourism and Hospitality Research, 7(2), 115 - 117.

Simmons, D.G. (1994). Community participation in tourism planning. Tourism Management 15(2), 98 - 108.

Tasci, A.D.A. \& Gartner, W.C. (2007). Destination image and its functional relationship. Journal of Travel Research, 45(40), $413-425$.

Telfer, D.J., \& Wall, G. (2000). Strengthening backward economic linkages: local food purchasing by three Indonesian hotels. Tourism Geographies 2(4), 421-447.

Tosun, C. (2006). Expected nature of community participation in tourism development, Tourism Management, 27 (3) $493-504$.

Turner, V. (1982). From ritual to theater: The human seriousness of play. New York: PAJ Publications.

Wood, N.B. (2007). Bringer of the Rain: The Naga Spirits of Asia. Retrieved from http://www.3worlds.co.uk/Articles/Snake-Spirits.pdf. World Tourism Organization, (2007). A Practical guide to tourism Destination Management. World Tourism Organization: Madrid.

Xie, P.F. (2004). Visitors' perceptions of authenticity at a rural heritage festival: a case study Event Management, 8, $151-160$. 